\title{
Anti-inflammatory effects of egg white combined with chalcanthite in lipopolysaccharide-stimulated BV2 microglia through the inhibition of NF-кB, MAPK and PI3K/Akt signaling pathways
}

\author{
EUN-A CHOI ${ }^{1 *}$, HYE YOUNG PARK ${ }^{2 *}$, HWA-SEUNG YOO $^{3}$ and YUNG HYUN CHOI ${ }^{4,5}$ \\ ${ }^{1}$ Insan Bamboo Salt Inc. and Insan Korean Medical Cancer Clinic, Hamyang 676-805; ${ }^{2}$ Department of Pharmacy, \\ Busan National University, Busan 609-735; ${ }^{3}$ Department of East-West Cancer Center, College of Oriental Medicine, \\ Daejeon University, Daejeon 301-724; ${ }^{4}$ Department of Biochemistry, Dongeui University College of Oriental Medicine, \\ Busan 614-052; ${ }^{5}$ Department of Biomaterial Control (BK21 Program), Anti-Aging Research Center and \\ Blue-Bio Industry RIC, Dongeui University, Busan 614-714, Republic of Korea
}

Received August 10, 2012; Accepted October 12, 2012

DOI: $10.3892 / \mathrm{ijmm} .2012 .1169$

\begin{abstract}
Egg white-chalcanthite (EWCC) is a mixture of egg white and chalcanthite prepared by roasting chalcanthite (which is a natural mineral mainly composed of $\mathrm{CuSO}_{4} \cdot 5 \mathrm{H}_{2} \mathrm{O}$ ) to the point of dehydration, pulverizing the dehydrated chalcanthite and then mixing the pulverized chalcanthite to react with egg white to trigger a reaction. When egg white-chalcanthite is prepared in this manner, the toxicity of chalcanthite is neutralized by the egg white, so that the toxicity is reduced or removed and the pharmaceutical properties are increased. However, the cellular and molecular mechanisms underlying the pharmacological activity of EWCC remain poorly understood. In this study, we investigated the inhibitory effects of EWCC on the production of lipopolysaccharide (LPS)-induced pro-inflammatory mediators in BV2 microglia. Our data indicated that the EWCC treatment significantly inhibited the excessive production of nitric oxide and prostaglandin $\mathrm{E}_{2}$ in LPS-stimulated BV2 microglia in a concentration-dependent manner without causing cytotoxicity. It also attenuated the expression of inducible nitric oxide synthase, cyclooxygenase-2 and pro-inflammatory cytokines, including interleukin- $1 \beta$ and tumor necrosis factor- $\alpha$. Moreover, EWCC exhibited anti-inflammatory properties by the suppression of nuclear factor- $\mathrm{\kappa B}(\mathrm{NF}-\kappa \mathrm{B})$ activation by blocking I $\mathrm{KB}-\alpha$ degradation, downregulation of extracellular signal-regulated kinase,
\end{abstract}

Correspondence to: Dr Yung Hyun Choi, Department of Biochemistry, Dongeui University College of Oriental Medicine, Busan 614-052, Republic of Korea

E-mail: choiyh@deu.ac.kr

${ }^{*}$ Contributed equally

Key words: egg white-chalcanthite, anti-inflammation, nuclear factor- $\kappa \mathrm{B}$, mitogen-activated protein kinase, phosphoinositide 3-kinase/Akt
c-Jun N-terminal kinase, p38 mitogen-activated protein kinase (MAPK) and phosphoinositide 3-kinase (PI3K)/Akt pathways. Our results indicate that the inhibitory effects of EWCC on LPS-stimulated inflammatory mediator production in BV2 microglia are associated with the suppression of the NF- $\mathrm{B}$, MAPK and PI3K/Akt signaling pathways. These findings suggest that EWCC may offer a substantial therapeutic potential for the treatment of neurodegenerative diseases that are accompanied by microglial activation.

\section{Introduction}

Minerals have been traditionally used in Oriental herbal medicine treatment, particularly for immune-related diseases in Korea, China and other Asian countries (1-3). Among them, chalcanthite is a richly colored blue water-soluble sulfate mineral, commonly found in the late-stage oxidation zones of copper deposits (4). The main ingredient of chalcanthite is $\mathrm{CuSO}_{4}$. $\mathrm{CuSO}_{4}$ exists as a series of compounds that differ in their degrees of hydration. The anhydrous form occurs as a rare mineral known as chalcocyanite. The hydrated copper sulfate occurs in nature as chalcanthite $\left(\mathrm{CuSO}_{4} \cdot 5 \mathrm{H}_{2} \mathrm{O}\right)$ and two of the rarer ones include bonattite $\left(\mathrm{CuSO}_{4} \cdot 3 \mathrm{H}_{2} \mathrm{O}\right)$ and boothite $\left(\mathrm{CuSO}_{4} \cdot 7 \mathrm{H}_{2} \mathrm{O}\right)$ (4). According to Oriental medicine, chalcanthite has sour, acrid, cold and toxic properties, and is affiliated with the liver meridian. Its main function is to eliminate toxins. Internally, it functions as a purgative and helps the body get rid of excess phlegm and toxins. Chalcanthite can also be applied externally to treat skin abscesses, reduce inflammation and remove necrotic tissue. The traditionally used dose of chalcanthite is between 0.3 and $0.6 \mathrm{~g}$ of powdered mineral, decocted in water for oral administration. Larger amounts can be used when chalcanthite is applied externally. However, chalcanthite is poisonous and should be used only with extreme caution. To date, due to safety issues concerning their cytotoxic mechanisms, many mineral medicines are rarely used.

In addition to being a quality protein source, egg whites contain many essential minerals including potassium, magne- 
sium, calcium, phosphorus, copper, zinc and iron. They are also a good source of riboflavin and selenium along with essential vitamins such as folate, B12, niacin betaine and choline (5-9). In Medieval times in the West, egg whites were used for medicinal purposes such as treating wounds, skin disorders and mending broken bones. At present, egg whites are considered one of the most nutrition-rich foods and are widely recommended for children, the elderly, athletes and patients with a variety of health conditions.

Egg white-chalcanthite (EWCC) is a mixture of egg white and chalcanthite and may be prepared by roasting the chalcanthite in order to dehydrate it. The dehydrated chalcanthite is then pulverized and the pulverized chalcanthite is mixed to react with the egg white in order to trigger a chemical reaction. In the egg white-chalcanthite prepared as noted above, the toxicity of the chalcanthite is neutralized by egg white, so that the toxicity is reduced or removed and the pharmaceutical properties are increased. Recently, it has been reported that EWCC inhibits the growth of human lung cancer NCI-H460 cells by inducing apoptotic cell death through caspase-3 activation (10). However, the precise biochemical mechanisms underlying EWCC-induced anti-inflammatory effects have not yet been clarified.

Microglia have conventionally been regarded as brain macrophages and have been proposed to play a major role in host defense and tissue repair in the central nervous system (CNS) (11). They are activated in response to environmental stress and exposure to lipopolysaccharide (LPS), interferon (IFN) $-\gamma$ and $\beta$-amyloid $(12,13)$. Activation of microglia results in the release of various bioactive molecules, including nitric oxide $(\mathrm{NO})$, prostaglandin $\mathrm{E}_{2}\left(\mathrm{PGE}_{2}\right)$, reactive oxygen species (ROS), monocyte chemoattractant protein-1 (MCP-1) and pro-inflammatory cytokines, such as interleukin (IL)-1 $\beta$, IL-6 and tumor necrosis factor- $\alpha$ (TNF- $\alpha)(14,15)$. Overproduction of these inflammatory mediators causes various severe neurodegenerative diseases, such as Alzheimer's disease, Parkinson's disease, cerebral ischemia, multiple sclerosis and trauma (16-18). Therefore, activated microglia have been shown to be a major cellular source of pro-inflammatory and/ or cytotoxic factors that cause neuronal damage in the CNS. Previous studies have also demonstrated that a decrease in the number of pro-inflammatory mediators in microglia attenuates the severity of these disorders (19-21). Thus, control of microglial activation may be an effective therapeutic option for the treatment of various neurodegenerative diseases.

LPS, the main component of endotoxins, initiates a number of major cellular effects that play critical roles in the pathogenesis of inflammatory responses and have been employed to induce microglial activation during infection by Gram-negative bacteria (22). Therefore, LPS stimulation of microglia is a useful model with which to study the mechanisms that underlie neuronal injury through various pro-inflammatory and neurotoxic factors released by activated microglia, such as NO, PGE 2 , ROS, IL-1 $\beta$, IL-6 and TNF- $\alpha(14,15,23)$. In addition, inflammation is the organized response of an organism to injuries of multiple pathologies and the response involves the speedy upregulation and activation of many genes. Among them, nuclear factor- $\kappa \mathrm{B}$ $(\mathrm{NF}-\kappa \mathrm{B})$ is a critical transcription factor involved in this response and is normally present in the cytoplasm by virtue of its association with the inhibitory protein, IкB (24-26). Once activated by inflammatory stimulants such as LPS, IкBs are rapidly phosphorylated and degraded by IкB kinase (IKK). $\mathrm{I} \kappa \mathrm{B}$ degradation liberates $\mathrm{NF}-\kappa \mathrm{B}$ to move into the nucleus, resulting in transcriptional induction of inflammation-associated genes $(27,28)$.

Based on these previous observations, the present study was designed to evaluate the inhibitory effects of EWCC on the LPS-stimulated inflammatory mediator production in murine BV2 microglia and the related anti-inflammatory mechanisms. As a result of our findings, we suggest that EWCC may be a candidate for the treatment of various neurodegenerative disorders.

\section{Materials and methods}

Preparation of EWCC. For the preparation of EWCC, chalcanthite was heated and dehydrated. During the heating process, chalcanthite was uniformly heated while carefully being watched for a color change every 3-5 h until it turned completely grey. The heating duration $(\sim 10-24 \mathrm{~h})$ varied with the amount and quality of the mineral used. Once the chalcanthite was dehydrated, it was cooled until the remaining heat was completely released. The moisture content of the chalcanthite ranged from 0 to 5\%. After cooling, chalcanthite was finely pulverized. The pulverized chalcanthite was stored in a concealed airtight container in a dry place to prevent moisture from accumulating. The prepared chalcanthite powder was mixed with egg whites at ratios of 30:13 to 30:30 for $10 \mathrm{~min}$. The egg whites needed to be homogeneously mixed with a wooden spatula in a ceramic vessel so the utensils would not interfere or cause any chemical reactions during the mixing process. After the chalcanthite and egg whites were sufficiently mixed, the mixture was cooled until the reaction heat was completely released. One hundred milligrams of the obtained substance was then dissolved in 1 liter of deionized water and centrifuged at $6,000 \mathrm{rpm}$ for $10 \mathrm{~min}$. A portion of the upper level concentration $(0.80 \mu \mathrm{m})$ was filtered by syringe filter after the centrifugation.

Cell culture. The murine BV2 cell line was maintained in DMEM supplemented with $10 \%$ fetal bovine serum (FBS), $100 \mathrm{U} / \mathrm{ml}$ penicillin and $100 \mu \mathrm{g} / \mathrm{ml}$ streptomycin at $37^{\circ} \mathrm{C}$ in a humidified incubator with $5 \% \mathrm{CO}_{2}$. Confluent cultures were passed by trypsinization. The cells used in the experiments were washed twice with warm DMEM (without phenol red) and treated in a serum-free medium for at least $4 \mathrm{~h}$ before treatments. In all experiments, the cells were treated with various concentrations of EWCC at the indicated times before the addition of LPS $(0.5 \mu \mathrm{g} / \mathrm{ml})$.

Cell viability assay. Cell viability was measured based on the formation of blue formazan that was metabolized from colorless MTT [3-(4,5-dimethylthiazol-2-yl)-2,5-diphenyltetrazolium bromide; Sigma, St. Louis, MO] by mitochondrial dehydrogenases, which are active only in live cells. BV2 cells were plated on 24-well plates at a density of $2 \times 10^{5}$ cells/well for $24 \mathrm{~h}$ and then washed. Cells incubated with various concentrations of EWCC were treated with or without LPS (Escherichia coli 026:B6; Sigma) for $24 \mathrm{~h}$ and 
Table I. Sequence of primers used for RT-PCR in this study.

\begin{tabular}{ll}
\hline Gene name & \multicolumn{2}{c}{ Sequences } \\
\hline iNOS & \\
Sense & 5'-ATG TCC GAA GCA AAC ATC AC-3' \\
Antisense & 5'-TAA TGT CCA GGA AGT AGG TG-3' \\
COX-2 & \\
Sense & 5'-CAG CAA ATC CTT GCT GTT CC-3' \\
Antisense & 5'-TGG GCA AAG AAT GCA AAC ATC-3' \\
TNF- $\alpha$ & \\
Sense & 5'-ATG AGC ACA GAA AGC ATG ATC-3' \\
Antisense & 5'-TAC AGG CTT GTC ACT CGA ATT-3' \\
IL-1 $\beta$ & \\
Sense & 5'-ATG GCA ACT GTT CCT GAA CTC AAC T-3' \\
Antisense & 5'-TTT CCT TTC TTA GAT ATG GAC AGG AC-3' \\
GAPDH & \\
Sense & 5'-CGG-AGT-CAA-CGG-ATT-TGG-TCG-TAT-3' \\
Antisense & 5'-AGC-CTT-CTC-CAT-GGT-GGT-GAA-GAC-3' \\
\hline
\end{tabular}

then incubated in $0.5 \mathrm{mg} / \mathrm{ml}$ MTT solution. Three hours later, the supernatant was removed and the formation of formazan was measured at $540 \mathrm{~nm}$ using a microplate reader (Dynatech MR-7000; Dynatech Laboratories).

NO production. Concentrations of NO in the culture supernatants were determined by measuring nitrite, which is a major stable product of NO, using the Griess reagent (Sigma). Cells $\left(5 \times 10^{5}\right.$ cells $\left./ \mathrm{ml}\right)$ were stimulated in 24 -well plates for $24 \mathrm{~h}$ and then $100 \mu \mathrm{l}$ of each culture medium was mixed with an equal volume of Griess reagent (1\% sulfanilamide/0.1\% N-(1naphthyl)-ethylenediamine dihydrochloride/2.5\% $\left.\mathrm{H}_{3} \mathrm{PO}_{4}\right)$. Nitrite levels were determined using an ELISA plate reader at $540 \mathrm{~nm}$ and nitrite concentrations were calculated by reference to a standard curve generated by known concentrations of sodium nitrite (29).

Measurement of $P G E_{2}$ production. BV2 cells were incubated with purpurogallin in either the presence or absence of LPS $(0.5 \mu \mathrm{g} / \mathrm{ml})$ for $24 \mathrm{~h}$. Following the manufacturer's instructions, a volume of $100 \mu \mathrm{l}$ of culture-medium supernatant was collected for determination of $\mathrm{PGE}_{2}$ concentration by ELISA (Cayman, Ann Arbor, MI) (29).

RNA isolation and RT-PCR. Total RNA was prepared using TRIzol reagent (Invitrogen Life Technologies, Carlsbad, CA) and primed with random hexamers for the synthesis of complementary DNA using M-MLV Reverse Transcriptase (Promega, Madison, WI), according to the manufacturer's instructions using DNAse I (1 U/ $\mu$ g RNA) pretreated total mRNA. Single stranded cDNA was amplified by a polymerase chain reaction (PCR) with primers for inducible nitric oxide synthase (iNOS), cyclooxygenase (COX)-2, IL-1 $\beta$, TNF- $\alpha$ and glyceraldhyde-3-phosphate dehydrogenase (GAPDH) (Table I). The following PCR conditions were applied - GAPDH: 18 cycles of denaturation at $94^{\circ} \mathrm{C}$ for $30 \mathrm{sec}$, annealing at $57^{\circ} \mathrm{C}$ for $30 \mathrm{sec}$ and extension at $72^{\circ} \mathrm{C}$ for $30 \mathrm{sec}$; iNOS, COX-2, IL-1 $\beta$ and TNF- $\alpha$ : 25 cycles of denaturation at $94^{\circ} \mathrm{C}$ for $30 \mathrm{sec}$, annealing at $52^{\circ} \mathrm{C}$ for a 30 -sec extension at $72^{\circ} \mathrm{C}$ for $30 \mathrm{sec}$. GAPDH was used as an internal control to evaluate the relative expression of COX-2, iNOS, IL-1 $\beta$ and TNF- $\alpha(30)$.

Protein extraction and western blot analysis. Cells were washed with PBS three times, placed at a temperature of $4^{\circ} \mathrm{C}$ and lysed for $30 \mathrm{~min}$ in lysis buffer $(20 \mathrm{mM}$ sucrose, $1 \mathrm{mM}$ EDTA, $20 \mu \mathrm{M}$ Tris-Cl, pH 7.2, $1 \mathrm{mM}$ DTT, $10 \mathrm{mM}$ $\mathrm{KCl}, 1.5 \mathrm{mM} \mathrm{MgCl}{ }_{2}$ and $5 \mu \mathrm{g} / \mathrm{ml}$ aprotinin). Lysates were then centrifuged at $12,000 \mathrm{rpm}$ at $4^{\circ} \mathrm{C}$. The protein concentration was measured using a Bio-Rad protein assay (Bio-Rad, Hercules, CA) according to the manufacturer's instructions. Equal amounts of protein (30-50 $\mu \mathrm{g})$ were separated electrophoretically using $8-10 \%$ sodium dodecyl sulfate-polyacrylamide gel electrophoresis (SDS-PAGE). The gel was then transferred to $0.45-\mu \mathrm{m}$ polyvinylidene fluoride (PVDF; Millipore, Bedford, MA) membranes. Membranes were soaked in blocking buffer (5\% skimmed milk) and then incubated with the primary antibodies (Table II). After thorough washing with PBST, horseradish peroxidase conjugated antibodies were applied and immune complexes were then visualized using the enhanced chemiluminescence (ECL) detection system according to the recommended procedure (Amersham). In a parallel experiment, cells were washed with ice-cold PBS and scraped; and cytoplasmic and nuclear proteins were then extracted using NE-PER ${ }^{\circledR}$ Nuclear and Cytoplasmic Extraction Reagents (Pierce Biotechnology, Inc., Rockford, IL).

Cytokine assays. The levels of IL-1 $\beta$ and TNF- $\alpha$ (R\&D Systems, Minneapolis, MN) were measured by ELISA kits according to the manufacturer's instructions. Briefly, BV2 cells $\left(5 \times 10^{5}\right.$ cells $\left./ \mathrm{ml}\right)$ were plated in 24 -well plates and pretreated with indicated concentrations of EWCC for $1 \mathrm{~h}$ before treatment of $0.5 \mu \mathrm{g} / \mathrm{ml}$ LPS for $24 \mathrm{~h}$. One hundred microliters of culture-medium supernatants was collected to determine the IL-1 $\beta$ and TNF- $\alpha$ concentrations by ELISA.

Immunofluorescence analysis. For detection of $\mathrm{NF}-\kappa \mathrm{B}$ p65 translocation, cells were grown on glass coverslips for $24 \mathrm{~h}$ and then treated with $0.5 \mu \mathrm{g} / \mathrm{ml} \mathrm{LPS}$, and were either pretreated or not pretreated with EWCC for $60 \mathrm{~min}$. Cells were fixed with $3.7 \%$ paraformaldehyde, treated with $0.2 \%$ Triton X-100 and blocked with $2 \%$ BSA. Cells were then sequentially incubated with the anti-NF- $\kappa$ B p 65 antibody, FITC-conjugated donkey anti-rabbit IgG and DAPI solution and examined using a fluorescence microscope (Carl Zeiss, Germany).

Statistical analyses. Data values represent the means \pm SD. Statistical significance was determined using an analysis of variance that was followed by the Student's t-test. A value of $\mathrm{P}<0.05$ was accepted as statistically significant.

\section{Results}

Effect of EWCC on NO and PGE $E_{2}$ production in LPS-stimulated $B V 2$ microglia. In the present study, we aimed to evaluate the 
Table II. List of antibodies used in this study.

\begin{tabular}{|c|c|c|c|}
\hline Antibody & Dilution & Product no. & Species of origin (supplier) \\
\hline iNOS & $1: 1,000$ & 610333 & Rabbit polyclonal (BD Biosciences) \\
\hline $\mathrm{COX} 2$ & $1: 500$ & SC-1999 & Mouse monoclonal (Santa Cruz Biotechnology) \\
\hline $\mathrm{NF}-\kappa \mathrm{B}$ p 65 & $1: 500$ & SC-109 & Mouse monoclonal (Santa Cruz Biotechnology) \\
\hline $\mathrm{I} \kappa \mathrm{B} \alpha$ & $1: 500$ & $\mathrm{SC}-847$ & Rabbit polyclonal (Santa Cruz Biotechnology) \\
\hline PI3K & $1: 500$ & 4257 & Mouse monoclonal (Cell Signaling Technology) \\
\hline p-PI3K & $1: 500$ & 4228 & Rabbit polyclonal (Cell Signaling Technology) \\
\hline Akt & $1: 500$ & SC-8312 & Rabbit polyclonal (Santa Cruz Biotechnology) \\
\hline $\mathrm{p}-\mathrm{Akt}$ & $1: 500$ & $9271 \mathrm{~S}$ & Rabbit polyclonal (Cell Signaling Technology) \\
\hline p38 & $1: 500$ & SC-728 & Rabbit polyclonal (Santa Cruz Biotechnology) \\
\hline ERK & $1: 2,000$ & $\mathrm{SC}-535$ & Rabbit polyclonal (Santa Cruz Biotechnology) \\
\hline JNK & $1: 500$ & 9252 & Rabbit polyclonal (Cell Signaling Technology) \\
\hline p-p38 & $1: 500$ & $9211 S$ & Rabbit polyclonal (Cell Signaling Technology) \\
\hline p-ERK & $1: 500$ & 9106S & Mouse monoclonal (Cell Signaling Technology) \\
\hline p-JNK & $1: 500$ & $9255 \mathrm{~S}$ & Mouse monoclonal (Cell Signaling Technology) \\
\hline Lamin B & $1: 1,000$ & NA12 & Mouse monoclonal (Oncogene Science) \\
\hline
\end{tabular}

A

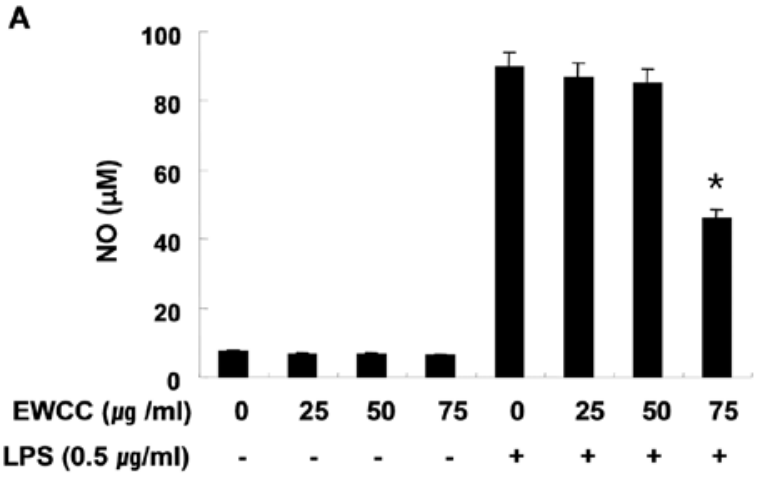

B

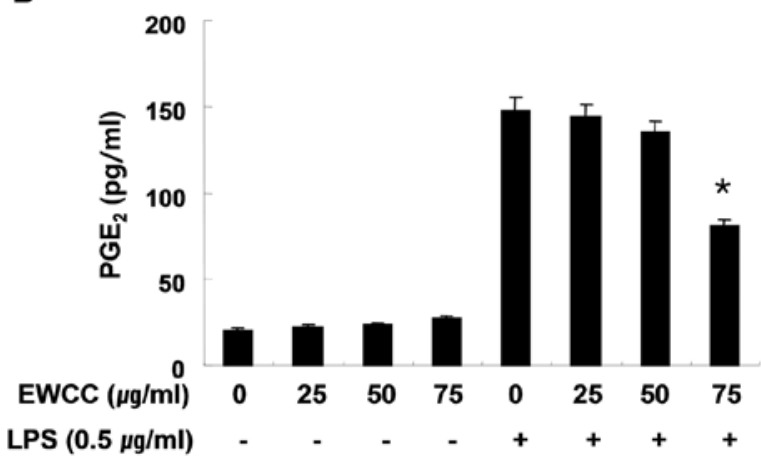

Figure 1. Inhibition of $\mathrm{NO}$ and $\mathrm{PGE}_{2}$ production by EWCC treatment in LPS-stimulated BV2 microglia. BV2 cells were pretreated with various concentrations of EWCC $(25,50$ and $75 \mu \mathrm{g} / \mathrm{ml})$ for $1 \mathrm{~h}$ before incubation with LPS $(0.5 \mu \mathrm{g} / \mathrm{ml})$ for $24 \mathrm{~h}$. (A) Nitrite content was measured using the Griess reagent and $(\mathrm{B}) \mathrm{PGE}_{2}$ concentration was measured in culture media using a commercial ELISA kit. Each value indicates the means $\pm \mathrm{SD}$ and is representative of the results obtained from three independent experiments. ${ }^{*} \mathrm{P}<0.05$ indicates a significant difference from the value obtained for cells treated with LPS in the absence of EWCC.

potential anti-inflammatory properties of EWCC regarding the production of two major inflammatory mediators, NO and $\mathrm{PGE}_{2}$, in LPS-stimulated BV2 microglia. To determine the level of NO production, we measured the nitrite released into the culture medium using Griess reagent. BV2 cells were pretreated with various concentrations of EWCC (25, 50 and $75 \mu \mathrm{g} / \mathrm{ml})$ for $1 \mathrm{~h}$ before being stimulated with LPS $(0.5 \mu \mathrm{g} /$ $\mathrm{ml})$. According to the NO detection assay, LPS alone was able to markedly induce NO production from the cells as compared to those generated by the control. However, pretreatment with EWCC significantly repressed the levels of NO production in LPS-stimulated BV2 microglia in a concentration-dependent manner of up to $75 \mu \mathrm{g} / \mathrm{ml}$ (Fig. 1A).

$\mathrm{PGE}_{2}$ represents another important inflammatory mediator that is produced from the conversion of arachidonic acid by COXs. Therefore, we next evaluated the inhibitory effects of EWCC on $\mathrm{PGE}_{2}$ levels present in the supernatant. To assess whether EWCC inhibits production of LPS-induced $\mathrm{PGE}_{2}$ in BV2 microglia, cells were pretreated with various concentrations of EWCC for $1 \mathrm{~h}$ and then stimulated with $0.5 \mu \mathrm{g} / \mathrm{ml}$ LPS. After incubation for $24 \mathrm{~h}$, the cell culture medium was harvested and the production of $\mathrm{PGE}_{2}$ was measured using an ELISA. As shown in Fig. 1B, the amount of $\mathrm{PGE}_{2}$ present in the culture medium increased from initial levels after $24 \mathrm{~h}$ of exposure to LPS alone, however a marked repression was observed after administration of EWCC in a concentrationdependent fashion.

Effect of EWCC on the cell viability in LPS-stimulated $B V 2$. In order to exclude the cytotoxic effect of EWCC on the cell growth of BV2 cells, the cells were exposed to various concentrations of EWCC for $24 \mathrm{~h}$ in the presence or absence of LPS, and cell viability was then measured by an MTT assay. Under the same condition, we also analyzed whether chromatin condensation, a hallmark of apoptosis, was induced by EWCC treatment. As indicated in Fig. 2, the concentrations of EWCC $(25-75 \mu \mathrm{g} / \mathrm{ml})$ used to inhibit $\mathrm{NO}$ and $\mathrm{PGE}_{2}$ production did not affect cell viability. These results clearly indicated that the inhibition of $\mathrm{NO}$ and $\mathrm{PGE}_{2}$ production in LPS-stimulated BV2 cells was not due to the cytotoxic action of EWCC. 


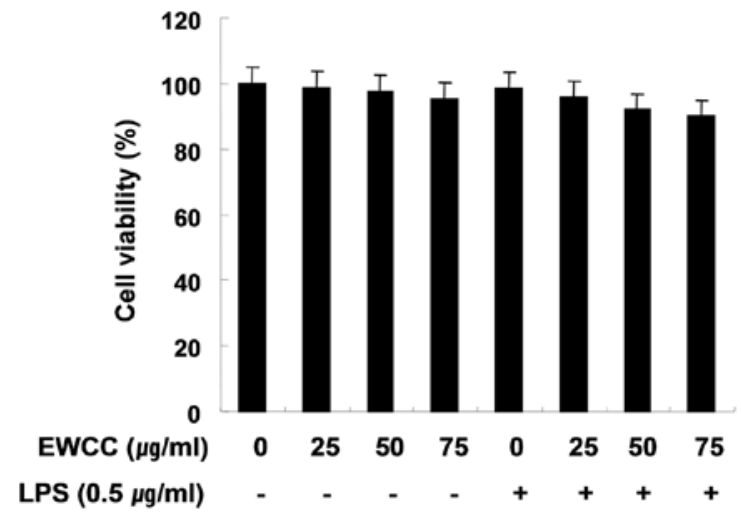

Figure 2. Effects of EWCC and LPS on cell viability of BV2 microglia. BV2 cells were treated with the indicated concentrations of EWCC and LPS $(0.5 \mu \mathrm{g} / \mathrm{ml})$ alone, or pretreated with the indicated concentrations of EWCC for $1 \mathrm{~h}$ before LPS treatment, After $24 \mathrm{~h}$, cell viability was assessed using an MTT reduction assay and the results are expressed as the percentage of surviving cells over control cells (no addition of EWCC). Each value indicates the means $\pm \mathrm{SD}$ and is representative of the results obtained from three independent experiments.

A

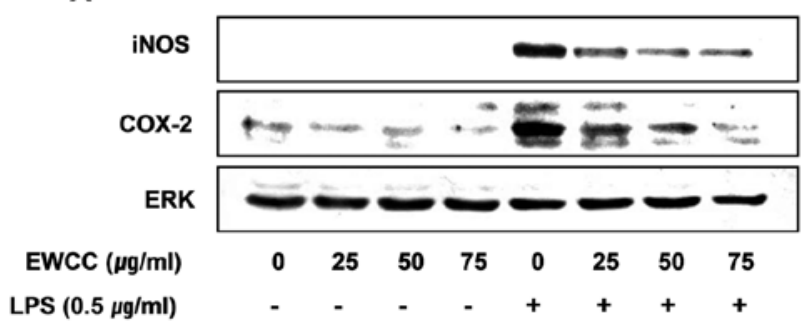

B

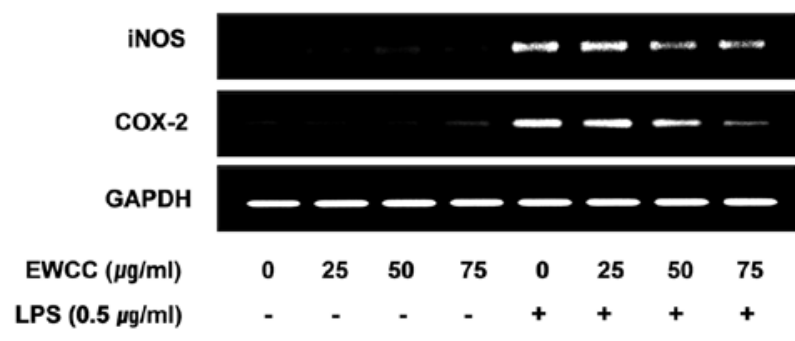

Figure 3. Inhibition of iNOS and COX-2 expression by EWCC in LPSstimulated BV2 microglia. (A) BV2 cells were pretreated with the indicated concentrations of EWCC $1 \mathrm{~h}$ prior to incubation with LPS $(0.5 \mu \mathrm{g} / \mathrm{ml})$ for $24 \mathrm{~h}$. Cell lysates were then prepared and western blotting was performed using antibodies specific for murine iNOS and COX-2. (B) After LPS treatment for $6 \mathrm{~h}$, total RNA was prepared for RT-PCR analysis of iNOS and COX-2 gene expression in LPS-stimulated BV2 microglia. Actin and GAPDH were used as internal controls for western blot analysis and RT-PCR assays, respectively. The experiment was repeated three times and similar results were obtained.

Effect of EWCC on LPS-stimulated levels of iNOS and COX-2 $m R N A$ and protein. To ascertain whether the inhibition of NO and the $\mathrm{PGE}_{2}$ production by EWCC treatment is associated with decreased levels of iNOS and COX-2, we performed RT-PCR and western blot analysis for detection of mRNA and protein levels. The levels of iNOS and COX-2 protein were markedly upregulated after $24 \mathrm{~h}$ of LPS $(0.5 \mu \mathrm{g} / \mathrm{ml})$ treatment,
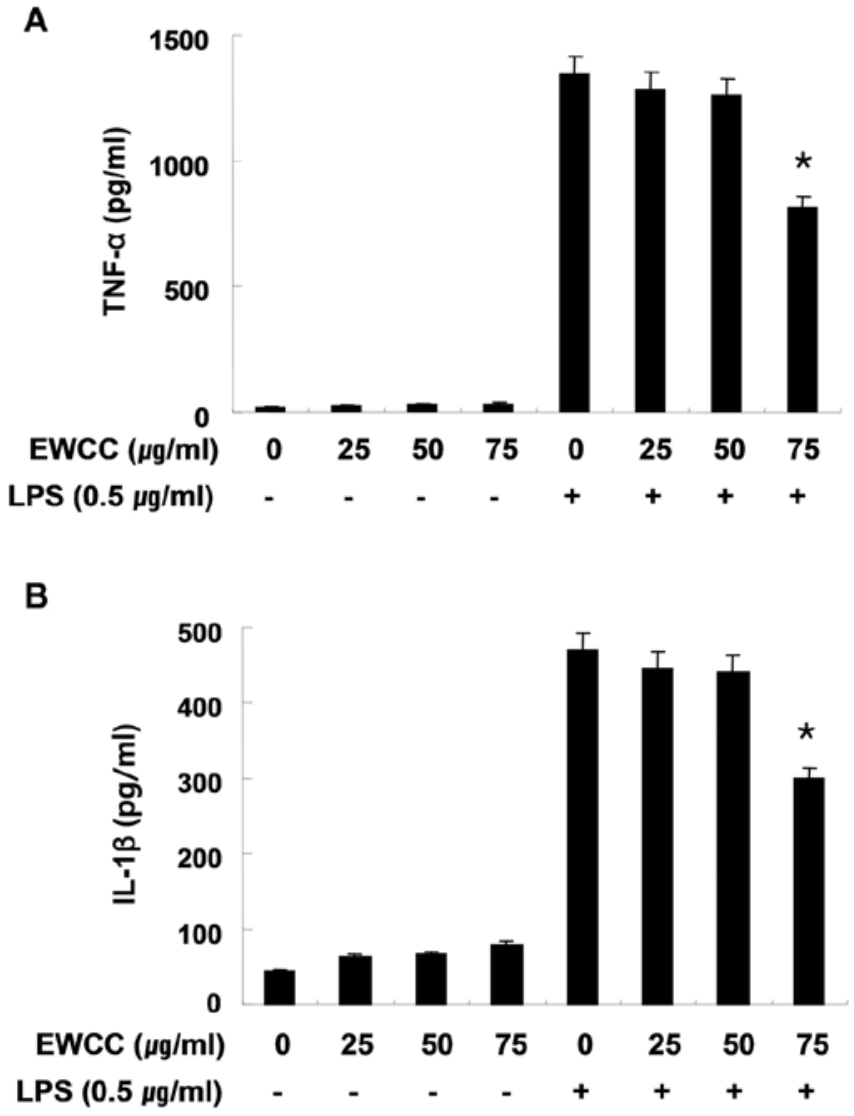

Figure 4. Effect of EWCC on the production of LPS-stimulated proinflammatory cytokines in BV2 microglia. BV2 cells were pretreated with various concentrations of EWCC for $1 \mathrm{~h}$ before LPS treatment $(0.5 \mu \mathrm{g} / \mathrm{ml})$. After incubation for $24 \mathrm{~h}$, the levels of (A) TNF- $\alpha$ and (B) IL-1 $\beta$ present in the supernatants were measured. Each value indicates the means \pm SD and is representative of the results obtained from three independent experiments. ${ }^{*} \mathrm{P}<0.05$ indicates a significant difference from the value obtained for cells treated with LPS in the absence of EWCC.

and EWCC significantly inhibited iNOS and COX-2 protein expression in LPS-stimulated BV2 microglia in a concentration-dependent manner (Fig. 3A). Next, to investigate whether or not EWCC suppresses the LPS-mediated induction of iNOS and COX-2 via a pretranslational mechanism, the effects of EWCC on iNOS and COX-2 mRNA expression were evaluated (Fig. 3B). RT-PCR analysis showed that the reduction in iNOS and COX-2 mRNA correlated with the reduction in the corresponding protein levels. The results suggest that EWCC-induced reduction in the expression of iNOS and COX-2 resulted in the inhibition of $\mathrm{NO}$ and $\mathrm{PGE}_{2}$ production.

Effects of EWCC on LPS-induced IL-1 $\beta$ and TNF- $\alpha$ production and $m R N A$ expression. We next investigated whether EWCC suppresses the production of pro-inflammatory cytokines, IL-1 $\beta$ and TNF- $\alpha$, in LPS-stimulated BV2 cells. BV2 microglia were incubated with EWCC in the absence or presence of $0.5 \mu \mathrm{g} / \mathrm{ml}$ of LPS for $24 \mathrm{~h}$ and the cytokine levels were evaluated in the culture supernatants. As indicated in Fig. $4 \mathrm{~A}$ and $\mathrm{B}$, induction of IL- $1 \beta$ and TNF- $\alpha$ by LPS treatment was significantly decreased by EWCC in cell culture media. In a parallel experiment, using RT-PCR, we studied the effects of EWCC on LPS-induced IL-1 $\beta$ and 


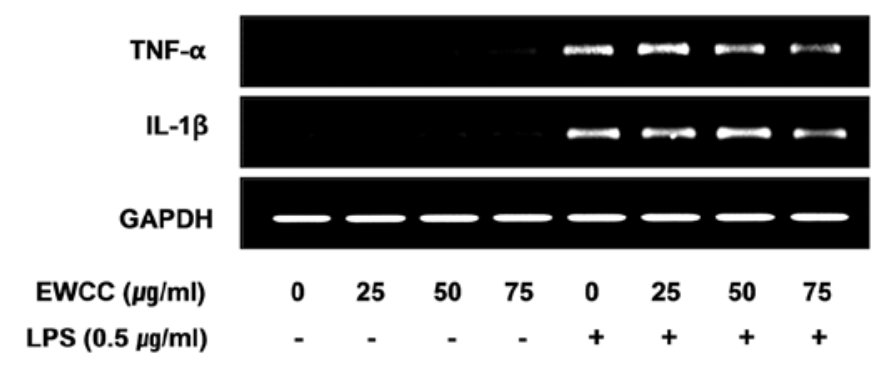

Figure 5. Effect of EWCC on LPS-stimulated IL-1 $\beta$ and TNF- $\alpha$ expression in BV2 microglia. BV2 cells were pretreated with various concentrations of EWCC for $1 \mathrm{~h}$ before LPS treatment $(0.5 \mu \mathrm{g} / \mathrm{ml})$ and the total RNA was isolated at $6 \mathrm{~h}$ after LPS treatment. The levels of IL-1 $\beta$ and TNF- $\alpha$ mRNA were determined using RT-PCR. GAPDH was used as an internal control.

A

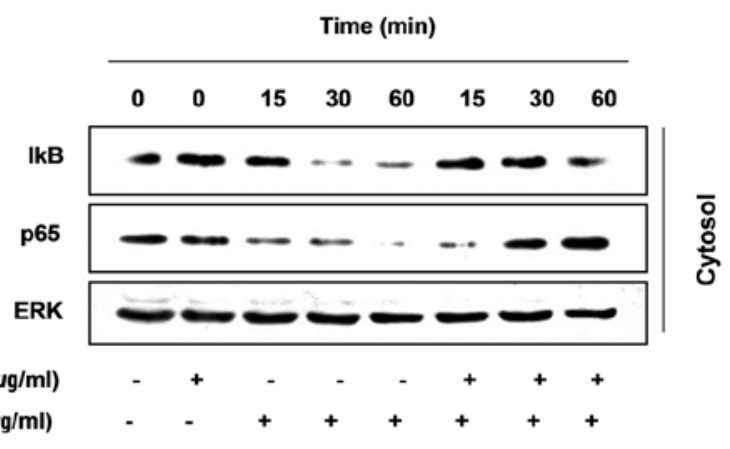

B

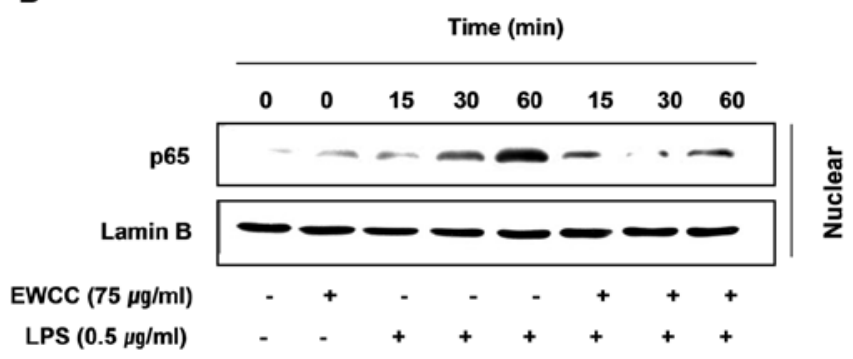

Figure 6. Effects of EWCC on LPS-induced NF-кB translocation and IкB degradation in BV2 microglia. Cells were treated with EWCC $(75 \mu \mathrm{g} / \mathrm{ml})$ for $1 \mathrm{~h}$ before LPS treatment $(0.5 \mu \mathrm{g} / \mathrm{ml})$ for the indicated times. (A) Cytosolic and (B) nuclear proteins were subjected to $10 \%$ SDS-polyacrylamide gels followed by western blotting using anti-NF- $\kappa \mathrm{B}$ p 65 and anti-IкB- $\alpha$ antibodies. The results are representative of those obtained from two independent experiments. ERK and lamin B were used as internal controls for cytosolic and nuclear fractions, respectively.

TNF- $\alpha$ mRNA expression. As shown in Fig. 5, IL-1 $\beta$ and TNF- $\alpha$ mRNA transcription also decreased following EWCC treatment. These results suggest that EWCC is effective in the suppression of pro-inflammatory cytokine production through the alteration of the transcription levels of IL- $1 \beta$ and TNF- $\alpha$ in activated microglia.

Effect of EWCC on LPS-induced NF- $\kappa B$ activity. NF- $\kappa \mathrm{B}$ is one of the important transcription factors that regulate gene expression of pro-inflammatory mediators including iNOS, COX-2, TNF- $\alpha$ and IL-1 $\beta$ in activated BV2 microglia (24-26); therefore, to further characterize the mechanism through which EWCC inhibits pro-inflammatory and/or cytotoxic factor expression, we examined whether EWCC prevents the

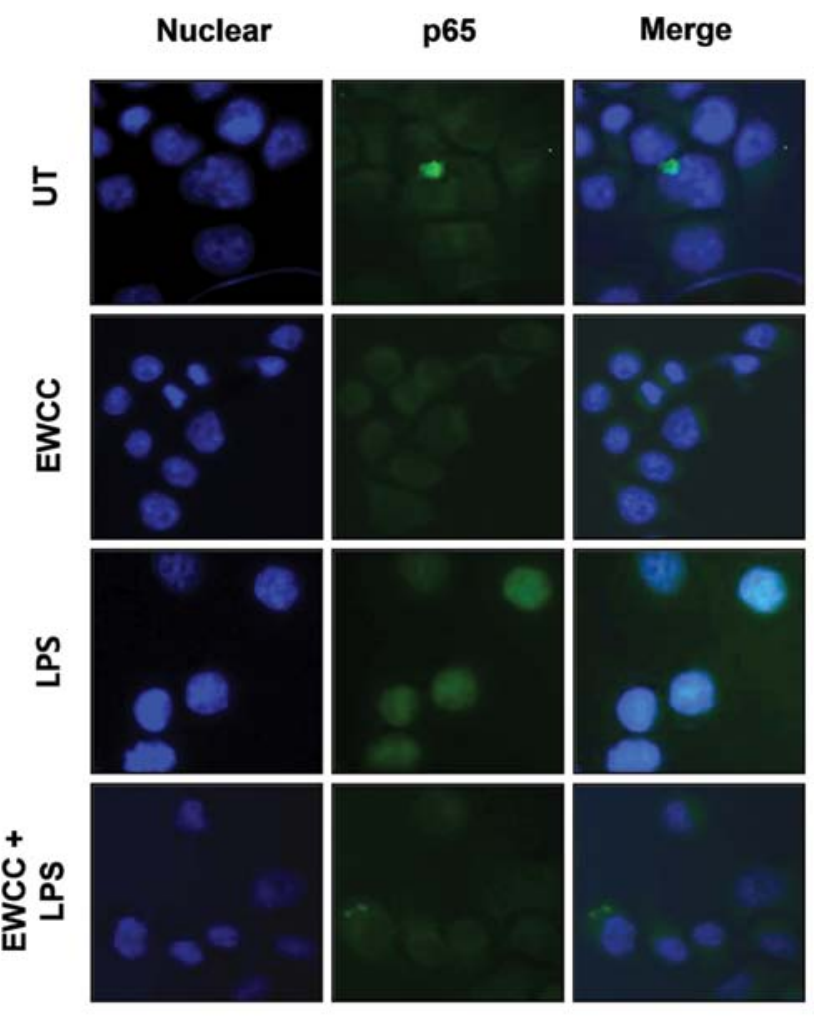

Figure 7. Inhibition of NF- $\mathrm{B}$ translocation by EWCC in LPS-stimulated $\mathrm{BV} 2$ microglia. Cells were treated with $\operatorname{EWCC}(75 \mu \mathrm{g} / \mathrm{ml})$ for $1 \mathrm{~h}$ before LPS treatment $(0.5 \mu \mathrm{g} / \mathrm{ml})$. After $1 \mathrm{~h}$ incubation, localization of $\mathrm{NF}-\kappa \mathrm{B}$ p65 was visualized with fluorescence microscopy after immunofluorescence staining with NF- $\mathrm{B}$ p65 antibody (green). Cells were also stained with DAPI for visualization of the nuclei (blue). Results are representative of those obtained from three independent experiments.

translocation of the p65 subunit of $N F-\kappa B$ to the nucleus. Western blot analysis showed that the amount of NF- $\mathrm{B}$ p65 in the nucleus was markedly increased after exposure to LPS alone, but the LPS-induced p65 level in the nuclear fractions was reduced by EWCC pretreatment (Fig. 6). Similar results were also found using immunofluorescence microscopy (Fig. 7). In addition, we investigated whether EWCC blocks the LPS-stimulated degradation of I $\mathrm{B}-\alpha$ using western blotting. As shown in Fig. 6, IкB- $\alpha$ was markedly degraded at $30 \mathrm{~min}$ after LPS treatment. However, this LPS-induced I $\kappa \mathrm{B}-\alpha$ degradation was significantly reversed by EWCC. These results suggest that EWCC inhibits $\mathrm{NF}-\kappa \mathrm{B}$ activation in BV2 microglia cells by suppression of $\mathrm{I} \kappa \mathrm{B}$ degradation and nuclear translocation of NF- $\mathrm{NB}$. Taken together the above findings show the anti-inflammatory effect of EWCC in the LPS-stimulated BV2 cells involved the NF- $\kappa$ B pathway.

Effects of EWCC on the LPS-induced activation of the PI3K/Akt pathway in BV2 microglia. Findings from recent studies have indicated that the phosphoinositide 3-kinase (PI3K)/Akt signaling molecule is able to trigger $\mathrm{NF}-\kappa \mathrm{B}$ activation through $\mathrm{I} \kappa \mathrm{B}$ degradation $(31,32)$. Therefore, we examined the effect of EWCC on LPS-induced PI3K/Akt activation. As shown in Fig. 8, phosphorylation of PI3K and Akt showed a marked increase within 15 min after LPS stimulation; however, EWCC pretreatment resulted in a significant 


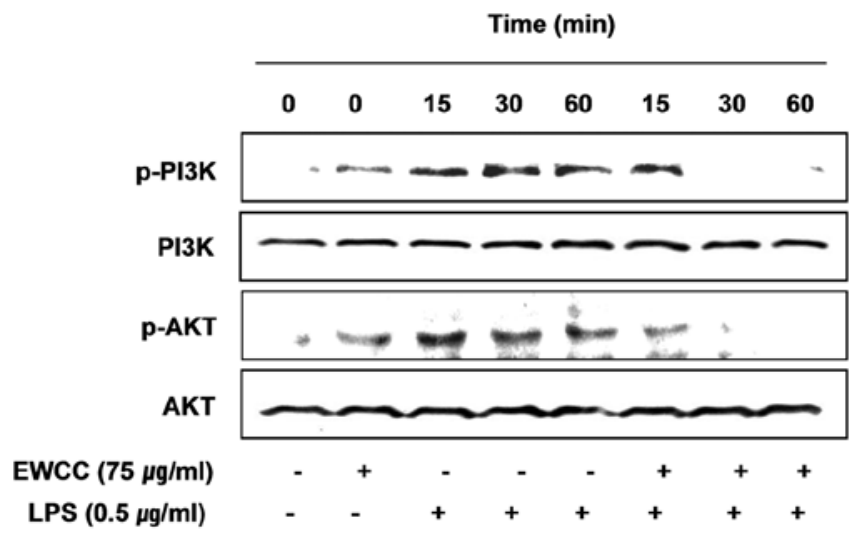

Figure 8. Effects of EWCC on PI3K and AKT activation induced by LPS in microglia. BV2 cells were treated with the indicated doses of EWCC $1 \mathrm{~h}$ before LPS treatment $(0.5 \mu \mathrm{g} / \mathrm{ml})$ for the indicated times. The total protein $(50 \mu \mathrm{g})$ was subjected to $10 \%$ SDS-PAGE, followed by western blotting using anti-p-PI3K, anti-PI3K, anti-p-Akt and anti-Akt antibodies. The results are representative of those obtained from three independent experiments.

blockage of LPS-induced PI3K and Akt phosphorylation. The results show that inhibition of pro-inflammatory mediator expression by EWCC in LPS-stimulated BV2 microglia was associated with the inactivation of the PI3K/Akt signaling pathway.

Effects of EWCC on the LPS-induced activation of MAPKs in BV2 microglia. Mitogen-activated protein kinases (MAPKs) are the most important signaling molecules with involvement in activated microglia $(33,34)$. Therefore, we determined the activation levels of the MAPK pathway at various times after LPS stimulation of BV2 cells. Stimulation of BV2 cells with LPS led to the rapid activation of p38MAPK, extracellular signal-regulated kinase (ERK) and c-Jun N-terminal kinase (JNK), with peak levels of each phospho-MAPK occurring 15-60 min after the addition of LPS. However, EWCC pretreatment significantly inhibited phosphorylation of MAPKs in LPS-stimulated BV2 microglia (Fig. 9). This finding suggests that EWCC is capable of disrupting key signal transduction pathways activated by LPS in BV2 microglia, which subsequently prevents the production of pro-inflammatory mediators.

\section{Discussion}

Microglia are brain macrophage cells that reside within the CNS. They play a pivotal role in the innate immune response of the CNS and serve as the first line of defense against invading pathogens (35). Activation of microglia by LPS induces the release of various pro-inflammatory mediators, such as IL-1 $\beta$, IL-6, TNF- $\alpha$, NO and PGE ${ }_{2}$, which have been implicated as important intermediaries of neuronal injury (14-16). In that regard, the inhibition of a variety of pro-inflammatory enzymes and cytokines would be an effective therapeutic approach against many neurodegenerative diseases. Many recent studies have reported the neuroprotective effects of natural extracts that are useful therapeutic agents for the protection of neurons from toxicities associated with exposure to activated microglia.

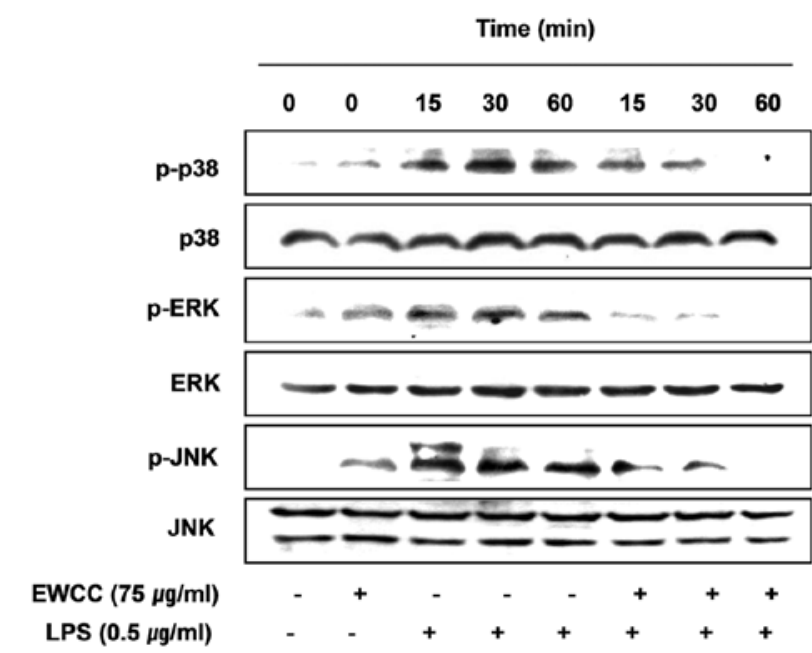

Figure 9. Effects of EWCC on MAPK activation induced by LPS in microglia. BV2 cells were treated with the indicated concentrations of EWCC $1 \mathrm{~h}$ before LPS treatment $(0.5 \mu \mathrm{g} / \mathrm{ml})$ for the indicated times. The total protein $(50 \mu \mathrm{g})$ was subjected to $10 \%$ SDS-PAGE, followed by western blotting using the indicated antibodies. Results are representative of those obtained from three independent experiments. Actin was used as the internal control.

The present results demonstrated that EWCC exhibits pharmacological and biological activities via significant inhibitory effects on the production of LPS-induced inflammatory mediators and cytokines in BV2 microglial cells. These mediators and cytokines include $\mathrm{NO}, \mathrm{PGE}_{2}, \mathrm{IL}-1 \beta$ and TNF- $\alpha$. The inhibitory effects were also mediated through the inhibition of NF- $\mathrm{kB}$ activation and the PI3K/Akt and MAPK pathways. These data suggest that EWCC may be a possible therapeutic agent for the treatment of inflammatory disease, including neurodegenerative disorders.

$\mathrm{NO}$ is an important regulatory molecule in a wide range of physiological and pathological processes. NO is produced from L-arginine by NO synthase (NOS), a three member enzyme family, including iNOS, which is produced mainly by activated glial cells (36). NO production can lead to inflammatory, infectious, ischemic, traumatic and neurodegenerative diseases (13,37-39). Thus, inflammatory diseases could be prevented through the inhibition of iNOS and NO. Similarly, $\mathrm{PGE}_{2}$ is also a well-known inflammatory mediator derived from arachidonic acid via the action of cyclooxygenases. The overproduction of $\mathrm{PGE}_{2}$ in response to growth factors, cytokines and pro-inflammatory molecules is associated with the upregulation of COX-2 $(40,41)$. COX-2 has emerged as one of the major players in brain inflammation and increased COX-2 expression is believed to contribute to neurodegeneration $(42,43)$. Therefore, intense research has been undertaken in order to search for selective COX-2 inhibitors. In the present study, EWCC inhibited both $\mathrm{PGE}_{2}$ and $\mathrm{NO}$ production in a concentration-dependent manner (Fig. 1) and these inhibitory effects were mediated through the downregulation of COX-2 and iNOS expression at the mRNA and protein levels (Fig. 3) without causing cytotoxicity (Fig. 2). Chronic microglial activation and consequent overproduction of pro-inflammatory cytokines, such as IL- $1 \beta$ and TNF- $\alpha$, are a histopathological hallmark of various neurological diseases $(14,15)$. The data 
also show that EWCC inhibits LPS-induced cytokine expression at the transcriptional level in BV2 microglia (Fig. 5).

$\mathrm{NF}-\kappa \mathrm{B}$, as a result of its key role in several pathologic conditions, is a major drug target in a variety of diseases. Activation of the $\mathrm{NF}-\kappa \mathrm{B}$ protein plays a pivotal role in inflammation due to its ability to induce transcription of pro-inflammatory genes. The activity of $\mathrm{NF}-\kappa \mathrm{B}$ is suppressed in the cytoplasm, while it is complexed with an inhibitory $\mathrm{I} \kappa \mathrm{B}$ protein. The phosphorylation of I $\mathrm{B}$ subsequently leads to its ubiquitination and degradation $(27,28)$. NF- $\kappa \mathrm{B}$ dimers are then free to translocate to the nucleus and activate target genes, including iNOS, COX-2 and pro-inflammatory cytokines. It is well known that the blockade of $\mathrm{NF}-\kappa \mathrm{B}$ transcriptional activity in the microglial nucleus can also suppress the expression of iNOS, COX-2 and pro-inflammatory cytokines, such as IL-1 $\beta$, IL- 6 and TNF- $\alpha(24,44)$. Recently, involvement of the PI3K/Akt pathway in the expression of inflammatory mediators in microglia through the activation of $\mathrm{NF}-\kappa \mathrm{B}$ has also been demonstrated $(31,32,45)$. Therefore, many current anti-inflammatory therapies seek to block NF- $\mathrm{B}$ activity. Our study indicated that EWCC inhibited the LPS-induced I $\mathrm{B}-\alpha$ degradation and that it inhibited the nuclear translocation of the p65 subunit of NF- $\mathrm{B}$ in BV2 microglia (Figs. 6 and 7). Therefore, inhibition of $\mathrm{NF}-\kappa \mathrm{B}$ signaling pathways in microglia by EWCC might result in the downregulation of pro-inflammatory mediators, resulting in an anti-inflammatory effect. Furthermore, EWCC significantly inhibited PI3K/Akt activation in LPS-stimulated BV2 microglia (Fig. 8), indicating that EWCC inhibits LPS-induced NF- $\kappa$ B activation via the inactivation of the PI3K/AKT signaling pathway.

The involvement of various intracellular signaling pathways, such as MAPK, in the induction of inflammatory mediators has also been reported $(33,34)$. Therefore, we determined whether EWCC tightly regulates the expression of MAPKs to induce anti-inflammatory effects in LPS-stimulated microglia. Our results indicated that EWCC is a potent inhibitor of the activation of MAPKs, such as p38MAPK, ERK and JNK, induced by LPS stimulation in BV2 microglia (Fig. 9), suggesting that the anti-inflammatory effects were also due to the inhibition of the MAPK signaling pathway.

In summary, the present results demonstrate that EWCC significantly attenuated the release of inflammatory mediators such as NO, PGE 2 , TNF- $\alpha$ and IL- $1 \beta$ in a concentration-dependent manner; in particular, it acted at the level of transcription in activated BV2 microglia. The inhibitory action of EWCC was mediated by the prevention of $\mathrm{NF}-\kappa \mathrm{B}$ activation and the inhibition of $\mathrm{I} \kappa \mathrm{B}$ degradation. In addition, the activation of PI3K/Akt and MAPKs was significantly decreased after pretreatment with EWCC in LPS-stimulated BV2 microglial cells. As a result of the findings presented in this study, EWCC may provide an effective treatment for many neurodegenerative diseases, and the pharmacology and mode of action of its active components must be further investigated.

\section{Acknowledgements}

This study was supported by the Blue-Bio Industry Regional Innovation Center (RIC08-06-07) at Dongeui University as a RIC program under the Ministry of Knowledge, Economy and Busan City.

\section{References}

1. Bielory L, Chiaramonte L, Ehrlich P and Field J: Alternative treatment for allergy and asthma. J Asthma 40 (Suppl): S47-S53, 2003.

2. Enrico P, Sirca D and Mereu M: Antioxidants, minerals, vitamins, and herbal remedies in tinnitus therapy. Prog Brain Res 166: 323-330, 2007.

3. Olaku O and White JD: Herbal therapy use by cancer patients: a literature review on case reports. Eur J Cancer 47: 508-514, 2011.

4. Nordstrom DK and Alpers CN: Negative pH, efflorescent mineralogy, and consequences for environmental restoration at the Iron Mountain Superfund site, California. Proc Natl Acad Sci USA 96: 3455-3462, 1999.

5. Latshaw JD and Osman M: Distribution of selenium in egg white and yolk after feeding natural and synthetic selenium compounds. Poult Sci 54: 1244-1252, 1975.

6. White HB III: Vitamin-binding proteins in the nutrition of the avian embryo. J Exp Zool (Suppl) 1: 53-63, 1987.

7. Stevens L: Egg white proteins. Comp Biochem Physiol B. 100: $1-9,1991$.

8. Jacobs K, Shen L, Benemariya $H$ and Deelstra H: Selenium distribution in egg white proteins. Z Lebensm Unters Forsch 196: 236-238, 1993.

9. Yamasaki K, Kajimura K, Nakano M, Yokoyama H, Yoneda K and Umezawa C: Effects of preparations of Chinese medicinal prescriptions on digestive enzymes in vitro and in vivo. Biol Pharm Bull 21: 133-139, 1998.

10. Choi EA, Kim KH, Yoo BC and Yoo HS: Induction of apoptotic cell death by egg white combined-chalcanthite on NCI-H460 human lung cancer cells. J Korean Pharmacopuncture Inst 12: 49-59, 2009 (In Korean).

11. Perry VH and Gordon S: Macrophages and microglia in the nervous system. Trends Neurosci 11: 273-277, 1988.

12. Zielasek $\mathbf{J}$ and Hartung HP: Molecular mechanisms of microglial activation. Adv Neuroimmunol 6: 191-222, 1996.

13. Block ML, Zecca L and Hong JS: Microglia-mediated neurotoxicity: uncovering the molecular mechanisms. Nat Rev Neurosci 8: 57-69, 2007.

14. Rankine EL, Hughes PM, Botham MS, Perry VH and Felton LM: Brain cytokine synthesis induced by an intraparenchymal injection of LPS is reduced in MCP-1-deficient mice prior to leucocyte recruitment. Eur J Neurosci 24: 77-86, 2006.

15. Lynch MA: The multifaceted profile of activated microglia. Mol Neurobiol 40: 139-156, 2009.

16. Gonzalez-Scarano F and Baltuch G: Microglia as mediators of inflammatory and degenerative diseases. Annu Rev Neurosci 22: 219-240, 1999.

17. Wirenfeldt M, Ladeby R, Dalmau I, Banati RB and Finsen B: Microglia - biology and relevance to disease. Ugeskr Laeger 167: 3025-3030, 2005 (In Danish).

18. Garden GA and Möller T: Microglia biology in health and disease. J Neuroimmune Pharmacol 1: 127-137, 2006.

19. Eikelenboom P and van Gool WA: Neuroinflammatory perspectives on the two faces of Alzheimer's disease. J Neural Transm 111: 281-294, 2004

20. Gao HM, Liu B, Zhang W and Hong JS: Novel anti-inflammatory therapy for Parkinson's disease. Trends Pharmacol Sci 24: 395-401, 2003.

21. Liu B and Hong JS: Role of microglia in inflammation-mediated neurodegenerative diseases: mechanisms and strategies for therapeutic intervention. J Pharmacol Exp Ther 304: 1-7, 2003.

22. Burroughs M, Cabellos C, Prasad S and Tuomanen E: Bacterial components and the pathophysiology of injury to the blood-brain barrier: does cell wall add to the effects of endotoxin in gramnegative meningitis? J Infect Dis 165 (Suppl 1): S82-S85, 1992.

23. Jung WK, Lee DY, Park C, Choi YH, Choi I, Park SG, Seo SK, Lee SW, Yea SS, Ahn SC, Lee CM, Park WS, Ko JH and Choi IW: Cilostazol is anti-inflammatory in BV2 microglial cells by inactivating nuclear factor-kappaB and inhibiting mitogenactivated protein kinases. Br J Pharmacol 159: 1274-1285, 2010.

24. Baldwin AS Jr: The NF-kappa B and I kappa B proteins: new discoveries and insights. Annu Rev Immunol 14: 649-683, 1996.

25. Lee SJ and Lee S: Toll-like receptors and inflammation in the CNS. Curr Drug Targets Inflamm Allergy 1: 181-191, 2002.

26. Harari OA and Liao JK: NF- $\mathrm{BB}$ and innate immunity in ischemic stroke. Ann NY Acad Sci 1207: 32-40, 2010.

27. Sarkar FH, Li Y, Wang Z and Kong D: NF-kappaB signaling pathway and its therapeutic implications in human diseases. Int Rev Immunol 27: 293-319, 2008. 
28. Mankan AK, Lawless MW, Gray SG, Kelleher D and McManus R: NF-kappaB regulation: the nuclear response. J Cell Mol Med 13: 631-643, 2009.

29. Lee YH, Jeon SH, Kim SH, Kim C, Lee SJ, Koh D, Lim Y, Ha K and Shin SY: A new synthetic chalcone derivative, 2-hydroxy-3',5,5'-trimethoxychalcone (DK-139), suppresses the Toll-like receptor 4-mediated inflammatory response through inhibition of the Akt/NF- $\mathrm{BB}$ pathway in BV2 microglial cells. Exp Mol Med 44: 369-377, 2012.

30. Lee SH, Kim DW, Back SS, Hwang HS, Park EY, Kang TC, Kwon OS, Park JH, Cho SW, Han KH, Park J, Eum WS and Choi SY: Transduced Tat-Annexin protein suppresses inflammation-associated gene expression in lipopolysaccharide (LPS)-stimulated Raw 264.7 cells. BMB Rep 44: 484-489, 2011.

31. Madrid LV, Wang CY, Guttridge DC, Schottelius AJ, Baldwin AS Jr and Mayo MW: Akt suppresses apoptosis by stimulating the transactivation potential of the RelA/p65 subunit of NF-kappaB. Mol Cell Biol 20: 1626-1638, 2000.

32. Wei J and Feng J: Signaling pathways associated with inflammatory bowel disease. Recent Pat Inflamm Allergy Drug Discov 4: 105-117, 2010.

33. Kim SH, Smith CJ and Van Eldik LJ: Importance of MAPK pathways for microglial pro-inflammatory cytokine IL-1 beta production. Neurobiol Aging 25: 431-439, 2004.

34. Zhang Y and Dong C: Regulatory mechanisms of mitogenactivated kinase signaling. Cell Mol Life Sci 64: 2771-2789, 2007.

35. Kreutzberg GW: Microglia: a sensor for pathological events in the CNS. Trends Neurosci 19: 312-318, 1996.

36. Ohshima $\mathrm{H}$ and Bartsch $\mathrm{H}$ : Chronic infections and inflammatory processes as cancer risk factors: possible role of nitric oxide in carcinogenesis. Mut Res 305: 253-264, 1994.

37. Murphy S: Production of nitric oxide by glial cells: regulation and potential roles in the CNS. Glia 29: 1-13, 2000.
38. Zekry D, Epperson TK and Krause KH: A role for NOX NADPH oxidases in Alzheimer's disease and other types of dementia? IUBMB Life 55: 307-313, 2003.

39. Brown GC and Bal-Price A: Inflammatory neurodegeneration mediated by nitric oxide, glutamate, and mitochondria. Mol Neurobiol 27: 325-355, 2003.

40. Minghetti L: Cyclooxygenase-2 (COX-2) in inflammatory and degenerative brain diseases. J Neuropathol Exp Neurol 63: 901-910, 2004.

41. St-Onge M, Flamand N, Biarc J, Picard S, Bouchard L, Dussault AA, Laflamme C, James MJ, Caughey GE, Cleland LG, Borgeat $\mathrm{P}$ and Pouliot M: Characterization of prostaglandin $\mathrm{E}_{2}$ generation through the cyclooxygenase (COX)-2 pathway in human neutrophils. Biochim Biophys Acta 1771: 1235-1245, 2007.

42. Kawano T, Anrather J, Zhou P, Park L, Wang G, Frys KA, Kunz A, Cho S, Orio M and Iadecola C: Prostaglandin $E_{2}$ EP1 receptors: downstream effectors of COX-2 neurotoxicity. Nat Med 12: 225-229, 2006

43. Hewett SJ, Uliasz TF, Vidwans AS and Hewett JA: Cyclooxygenase- 2 contributes to $\mathrm{N}$-methyl-D-aspartate-mediated neuronal cell death in primary cortical cell culture. J Pharmacol Exp Ther 293: 417-425, 2000.

44. Moon DO, Choi YH, Kim ND, Park YM and Kim GY: Anti-inflammatory effects of beta-lapachone in lipopolysaccharide-stimulated BV2 microglia. Int Immunopharmacol 7: 506-514, 2007.

45. Lee JY, Jhun BS, Oh YT, Lee JH, Choe W, Baik HH, Ha J, Yoon KS, Kim SS and Kang I: Activation of adenosine A3 receptor suppresses lipopolysaccharide-induced TNF-alpha production through inhibition of PI 3-kinase/Akt and NF-kappaB activation in murine BV2 microglial cells. Neurosci Lett 396: 1-6, 2006. 